\title{
Bullinger en die verbond na aanleiding van die Tweede Switserse Konfessie*
}

\author{
SJ Botha
}

\begin{abstract}
Bullinger's concept of the covenant and the Confessio Helvetica Posterior

The Confessio Helvetica Posterior is not only one of the most extensive confessions of the Reformed churches but it is also very widely accepted. The composer of the confession was JH Bullinger (1504-1575) who was one of the first, if not the first, Reformer to make use of the concept of the covenant in his theological thinking. Bullinger's specific idea of a bilateral or conditional covenant is most probably unprecedented in Christian Thought and in this respect he not only differed from Calvin but he also initiated another tradition in reformed Protestantism. Basically the Confessio Helvetica Posterior is nothing else than an unfolding of Bullinger's concept of the covenant.
\end{abstract}

\section{DIE TWEEDE SWITSERSE GELOOFSBELYDENIS $\mathbf{1 5 6 6}$}

Op 12 Maart 1566 het die Confessio Helvetica Posterior in Zürich gelyktydig in Latyn en Duits verskyn met insteming van die gereformeerde kerke van Zürich, Genève, Bern, Schaffhausen, Biel, St Gallen en Mühlhausen (De Klerk 1954: 63; Leith 1973: 131). Kort daarna het die kerk van Basel ook instemming verleen. Dit het meegebring dat die Switserse hervorming, sowel Duits- as Franssprekend, nou tot 'n hegter eenheid saamgebind is. Selfs buite Switserland is hierdie Konfessie ook spoedig deur die Reformatoriese kerke van die Paltz, Frankryk, Skotland, Hongarye en Pole aanvaar. Ook in Nederland en Engeland het hierdie Konfessie hoë aansien geniet. Ongetwyfeld het die wye aanvaarding en erkenning van die Konfessie ' $n$ baie belangrike bydrae gelewer om groter eenheid in die gereformeerde Protestantisme te bewerk, nie alleen in Switserland nie, maar ook in die hele Wes-Europa. Sommige navorsers beskou die Konfessie, naas die Heidelbergse Kategismus, as die mees gesaghebbende van alle Europese gerefor-

- Referaat gelewer voor die Kerkhistoriese Genootskap van die Nederduitsch Hervormde Kerk op 20 November 1984. 
meerde simbole. Ander oordeel dat dit nòg as Calvinisties nòg as Zwingliaans, maar wel as 'n hoëre eenheid tussen beide rigtings, gesien moet word (De Klerk 1954: 63). Met die totstandkoming van die Gereformeerde Ekumeniese Sinode in 1946 is die Konfessie as een van die simbole aanvaar wat as grondslag moes dien.

Behalwe die wye aanvaarding wat die Konfessie geniet het, was dit ook een van die mees uitgebreide van die Reformatoriese kerke. Die verskillende leerstukke is in dertig hoofstukke redelik uitvoerig behandel. Krities beskou ontbreek hier die skerper en helderder formulering van byvoorbeeld die Nederlandse Geloofsbelydenis en die Westminister Confession of Faith (Leith 1973: 131). Interessant egter is die aandag wat in die Konfessie gegee word aan aspekte soos die kerkorde, die erediens en die huwelik.

\section{DIE OPSTELLER VAN DIE KONFESSIE}

Die opsteller van die Konfessie was Johann Heinrich Bullinger (1504-1575), die opvolger van Huldrich Zwingli (1484-1531), as Reformator van Zürich. Bullinger, wat ook medewerker was aan die Confessio Helvetica Prior, het hierdie tweede Konfessie reeds so vroeg as $1561 / 62$ as 'n getuienis van sy geloof opgestel.

In 1564, tydens 'n baie hewige pes-epidemie te Zürich, het Bullinger die Konfessie vollediger uitgewerk en aan sy testament aangeheg (De Klerk 1954: 62). Twee gebeurtenisse het egter daartoe gelei dat dit nie maar net Bullinger se persoonlike geloofsbelydenis sou bly nie. Eerstens het keurvors Frederik van die Paltz 'n verdediging van sy gereformeerde geloof teenoor die Lutherane nodig gehad en Bullinger se geloofsbelydenis het hom uitstekend daartoe geleen. Tweedens het 'n ernstige behoefte by die Switserse kerke aan 'n meer uitgebreide konfessie as die beknopte Confessio Helvetica Prior ontstaan. Ook in hierdie behoefte het Bullinger se geloofsbelydenis voorsien. So het die persoonlike geloofsbelydenis van Bullinger een van die kosbare gereformeerde simbole geword.

Die wye aanvaarding en erkenning van ' $n$ geloofsbelydenis uit sy pen, kan gesien word as teken van die besonder wye invloed wat hy in die Reformatoriese kerke gehad het. Waar Calvyn die helder sistematiese en kompromislose denker was, was Bullinger die ireniese figuur wat as vader, wat 'n weldadige invloed gehad het, binne die kerke waardeer is. Hy het hom besonder beywer vir die eenheid van die gereformeerde Protestantisme. 
Dit is egter uiters merkwaardig dat Bullinger, wat in sy eie tyd so ' $n$ invloedryke kerklike figuur was, mettertyd in die Reformatoriese kerke byna geheel-en-al op die agtergrond geraak het. Hy het in 'n groot mate 'n skadufiguur geword oor wie daar nie so baie bekend is nie (Baker 1980: xii). Dit is jammer, aangesien Bullinger inderdaad ' $n$ uiters belangrike plek in die historiese ontwikkeling van die gereformeerde tradisie ingeneem het.

Dit is veral belangrik vanweë die feit dat Bullinger as die eerste werklike Reformatoriese verbondsteoloog gesien kan word en sodoende ook die vader van die latere verbondsteologie, veral ook soos dit in die Nederlandse Hervormde Kerk ontwikkel het. En juis as verbondsteoloog het hy ' $n$ eie weg gegaan en is duidelike verskille tussen, nie alleen sy teologie en dié van die Lutherane en die Anabaptiste nie, maar selfs tussen sy teologie en dié van Calvyn en die Calviniste aanwysbaar. Op die wyse het Bullinger 'n enigsins ander Reformatoriese tradisie geïnisieer (Baker 1980: 165). Ten opsigte van sy beskouing van die verbond, die predestinasie en die Christelike gemeenskap het Bullinger in ' $n$ ander rigting gedink. Basies egter het sy anderse denke in sy bepaalde verbondsopvatting ontspring. Bullinger se verbondsleer was die konstituerende in sy totale teologiese denkstruktuur (Koch 1968: 416) en dit het al in al sy teologiese werke na vore gekom, ook in die Confessio Helvetica Posterior.

\section{DIE VERBONDSBEGRIP IN DIE KONFESSIE}

Dit is merkwaardig dat die begrip verbond of foedus relatief selde in die Konfessie gebruik word; trouens in werklikheid slegs vyf keer (Koch 1968: 387, 417). Die begrip word in Caput XVII as wisselbegrip vir testamentum gebruik en in Caput XX vier keer in verband met die doop.

Dit laat Koch (1968: 387) opmerk:

'Bereits daraus ist ersichtlich, das er seinem Wesen nach in besonderer Affinität zur Sakraments-, speziell zur Tauflehre zu stehen scheint'.

Selfs in 'n sentrale hoofstuk van die Konfessie soos Caput XIII waar gehandel word 'De Evangelio Jesu Christi, de Promissionibus item, Spiritu et Lettera', word die begrip nie gebruik nie (Koch 1968: 383).

Die feit dat die begrip relatief min gebruik word, kan egter geensins tot die gevolgtrekking lei dat die verbondsleer van Bullinger maar ' $n$ geringe rol in die Konfessie gespeel het nie. Die teendeel is waar. Daarom stel Koch, wat die teologie van die Konfessie sorgvuldig nagegaan het, onomwonde: 
'Die Analyse der Theologie der Confessio sowohl in ihren Einzelgliedern wie auch nach ihrer Gesamtkonzeption hat nach einer zwingenden inner Logik selbst auf diesen Begriff und seine Struktur hingeführt. Der Bundesbegriff hat also für die Confessio zentrierende und umgreifende Bedeutung' (Koch 1968: 417).

Uiteindelik is die Konfessie niks anders as 'n ontvouing van Bullinger se verbondsbegrip nie (Koch 1968: 415).

Dogmaties gesien vertoon die Konfessie 'n besondere geslotenheid en indrukwekkende teologiese logika. Nie alleen word die onderskeie leerstukke vir ' $n$ konfessie redelik uitvoerig behandel nie, maar ook word al die leerstukke aan 'n allesomvattende opvatting diensbaar gemaak. En die allesomvattende opvatting is niks anders as die verbondsleer van Bullinger nie (Koch 1968: 415). Dit geld nie net die algemene tendens en opvatting van die Konfessie nie, maar elke afsonderlike deel is in wese ' $n$ nadere uitwerking van Bullinger se verbondsleer. Die Konfessie kan dus alleen werklik ten volle begryp word in die lig van Bullinger se verbondsleer en daarom moet hierop kortliks ingegaan word.

\section{OORSPRONG VAN DIE VERBONDSLEER}

Hoewel daar eenstemmigheid bestaan dat die oorsprong van die verbondsidee in Zürich by Zwingli en Bullinger gesoek moet word, is daar tog twyfel oor wie van Zwingli of Bullinger of dalk selfs die Anabaptiste eerste met die begrip foedus begin opereer het. Zwingli was blykbaar wel die eerste om die begrip in 'n geskrif te gebruik en die eerste skrede in die ontwikkeling van 'n verbondsleer te gee. Dit het hy juis in 1525 in sy kontrovers met die Wederdopers gedoen (Pont 1984: 68). Bullinger het egter baie kort na Zwingli, nog in 1525, ook die begrip begin gebruik. Die waarskynlikste oplossing blyk die konklusie van J Wayne Baker te wees, naamlik dat die ontwikkeling van die verbondsdenke in Zürich eerder 'n gesamentlike poging was van Zwingli en Bullinger waarin Zwingli die leiding geneem het (Baker 1980: 1-22). Die leiding het egter eerder in chronologiese as saaklike leiding bestaan. Zwingli het wel voor Bullinger die begrip foedus in sy argumente teen die Anabaptiste in 1525 begin gebruik, maar Bullinger het op sy beurt, reeds so vroeg as 1523, in 'n geskrif verskeie elemente wat in sy verbondsdenke essensieel is, na vore gebring.

In die geskrif De Scripturae Negotio van 30 November 1523 het Bullinger baie sterk klem gelê op die eenheid van die testamente; iets wat Zwingli eers in 1525 ingesien het (Baker 1980: 5). Trouens Baker sluit selfs nie die moontlikheid uit dat Bullinger hier reeds die eenheid van 
die verbond op die oog gehad het nie. Die eenheid van die testamente het vir Bullinger in sowel ' $n$ soteriologiese as ' $n$ hermeneutiese eenheid bestaan. Soos Zwingli later, het Bullinger die Ou Testament as die belofte en die Nuwe as die vervulling gesien. Jesus Christus was doel en middelaar van sowel die $\mathrm{Ou}$ as die Nuwe Testament. Met hierdie soteriologiese eenheid was die hermeneutiese eenheid in korrelasie. Omdat Jesus Christus die doel en middelaar van die Ou Testament was, daarom is die Nuwe Testament niks anders as die interpretasie van die $\mathrm{Ou}$ Testament nie. Al hierdie sake was belangrike elemente in Bullinger se verbondsdenke, soos hy dit vanaf 1525 noukeuriger uitgewerk het.

Daar is natuurlik nog die moontlikheid dat beide Zwingli en Bullinger in hulle beskouing op die patres teruggegryp het (Baker 1980: 19-24). Nie een van die twee het ooit aanspraak gemaak op oorspronklikheid vir hulle verbondsdenke nie en Bullinger self het hom dikwels beroep op figure soos Augustinus, Irenaeus, Tertullianus, Lactantius en die kerkhistorikus Eusebius. Feit is egter dat dit veral Bullinger se verbondsbeskouing was wat van al hierdie patres verskil het, met Irenaeus as moontlike uitsondering. Die verskil het veral daarmee te doen dat Bullinger 'n bilaterale of voorwaardelike verbondsleer daargestel het, terwyl al die bogenoemdes, behalwe moontlik Irenaeus, 'n eensydige testamentsbegrip nagehou het. In die geval van Irenaeus is daar sekere elemente wat op ' $n$ bilaterale verbondsidee kan dui. Bullinger self verwys slegs twee keer na Irenaeus in verband met sy verbondsopvatting. Baker is van mening dat Bullinger moontlik meer deur Irenaeus beinvloed is, as wat hy self wou toegee (Baker 1980: 21).

Ook nie die gedagtes van die Middeleeuse nominalisme, soos byvoorbeeld verteenwoordig deur Gabriel Biel wat 'n semi-Pelagiaanse bilaterale verdrag op die oog gehad het, het in formulering en intensie met Bullinger se verbondsleer iets in gemeen gehad nie (Baker 1980: 23).

Dit wil voorkom of Bullinger se bilaterale verbondsleer iets nuuts en waarskynlik sonder presedent in die Christelike denke was (Baker 1980: 25).

\section{BULLINGER SE ONTWIKKELING VAN 'N VERBONDSTEOLOGIE}

Die eerste keer dat Bullinger die begrip begin gebruik het was in sy geskrif 'Von dem Touff' van laat 1525. Baie van die gedagtes in die geskrif is wel reeds deur Zwingli gebruik, maar tog was Bullinger se 
verbondsgedagte geensins 'n replika van die van Zwingli nie. Veral twee nuwe fasette het by Bullinger na vore gekom en op hierdie twee fasette het hy in die verdere ontwikkeling van sy verbondsteologie later nader ingegaan. Die eerste was dat die verbond nie eerste met Abraham nie, maar wel met Adam gesluit is. Bullinger het dit duidelik gestel.

'Ihn (den Bund) schlos er aber nicht zuerst mit Abraham, sondern mit diesem erneuerte er nur den alten. Er schlos ihn aber zuerst mit Adam, unser aller Vater' (Koch 1968: 396).

Dieselfde verbond met Adam is weer met Henog, Noag en die duidelikste en uitdruklikste met Abraham aangegaan (Koch 1968: 397). In wese was dit daarom niks anders as ' $n$ hernuwing en verdere verklaring van die oorspronklike verbond nie en hierdie hernuwing van dieselfde verbond is telkens weer herhaal met andere, soos Isak, Jakob, Moses en so meer, totdat 'n era tot 'n einde gekom het en die verbondsbelofte in vervulling gegaan het in die tyd van Johannes die Doper, die wegbereider van Jesus Christus, die Messias, wat die belofte van die verbond was (Koch 1968: 398).

Vir Bullinger het dit duidelik vasgestaan: 'Der erste, klar fasbare Bundesschlus ist der mit Adam im Protevangelium' (Koch 1968: 395). Vanuit hierdie Proto-evangelie gaan die redenasie dan verder: 'Das Protevangelium ist die Urzelle der Bundesverheissung, die verheissung des Messias ist. Von da aus führt die linea Messie weiter über Noah zu Sem, Abraham, den Erzvätern, Mose, David, den Propheten bis zu ihrer Erfüllung in Christus' (Koch 1968: 397).

Van Jesus Christus moet dan gesê word:

'Die Bedeutung Christi besteht daarin, das er den Adambund exelentissime ommium purissime et clarissime erlaütert, ihn in ein breve compendium, das sog. novum foedus seu (=sive) novum testamentum zusammengefast und durch seinen Tod vollendet oder ratifiziert hat ... Die botschaft der Evangelien ist es gerade, Christum Ieseum aliud nihil esse quam aeterni foederis aeternum obsidem atque misericordiae et veritatis Dei testem' (Koch 1968: 399).

Hiermee het duidelik geword dat Bullinger die verbond vanuit 'n bepaalde historiese perspektief benader het. Die hele menslike geskiedenis is so onder die verbond ingesluit. Die geskiedenis van die volk van God, die geskiedenis van die heil, was daarom die geskiedenis van die verbond. Die verbond was die struktuur waarbinne God met sy volk, sy kerk, handel vanaf die begin tot die einde. Bullinger het dus 
die geskiedenis van God se volk in terme van die verbond gesien (Baker 1980: 55).

'Die heilsgeschichtliche Offenbarung Gottes und das Handeln

Gottes geschehen ja immer in der Weise eines Bündesverhältnisses' (Koch 1968: 399).

Hierdie selfde verbond word ook tot vandag met die gelowige en sy nageslag gesluit. Jesus Christus is die substansie van hierdie verbond, want Jesus Christus is die boodskap en sin van die Ou Testament. Christene durf daarom nie die Ou Testament verwerp nie, want die gees en essensie van die verbond is dieselfde in beide die $\mathrm{Ou}$ en die Nuwe Testament. Verder kan die Nuwe Testament nie sonder die Ou Testament verstaan word nie en die Ou Testament word op sy beurt deur die Nuwe Testament uitgelê. Dit is dus duidelik dat Bullinger nie alleen 'n eenheid tussen die twee testamente verstaan het nie, maar in noue verband daarmee ook ' $n$ eenheid van die verbond.

Dit bring die vraag na vore waarom nog gepraat word van 'n ou en nuwe verbond asof daar twee verbonde is (Baker 1980: 7). Bullinger stel baie duidelik dat daar wel net een verbond is, maar dat van die ou verbond in die tyd voor Christus sprake is, omdat Christus toe nog net in die seremonies beloof is. In die tyd na Christus is daar van die nuwe verbond sprake, omdat Christus die seremonies vervul het en alles nuut geword het. Verder is die verbond nou ook met 'n nuwe volk, wat ook die heidene ingesluit het, aangegaan en laastens is die verbondsteken ook verander: Vanaf Johannes die Doper het die doop die besnydenis as teken van die volk van God vervang (Baker 1980: 7).

Terloops kan daarop gewys word dat hiermee die hele problematiek van die kinderdoop vir Bullinger besleg was. Waar daar slegs een verbond was en die kinders voor Christus deur die destydse verbondsteken, naamlik die besnydenis, in die verbond ingelyf is, is dit vanselfsprekend dat die kinders ook nou ná Christus, deur die huidige verbondsteken, naamlik die doop, in die verbond ingesluit word.

Die tweede nuwe en baie belangrike onderskeidende faset wat Bullinger reeds in 1525 na vore gebring het en later nader uitgewerk het, was dat die verbond ' $n$ bilaterale of voorwaardelike of 'doppelseitiges Vertragverhältnis' was (Koch 1968: 388), (Baker 1980: 15). Hierin het Bullinger baie beslis ' $n$ ander weg gegaan en ' $n$ ander tradisie in die gereformeerde Protestantisme geïnisieer. Byna al die Reformatoriese vadere het die begrip verbond dikwels gebruik, maar dan gewoonlik idiomaties saam met ' $n$ hele aantal ander begrippe waaronder ook predestinasie, om die grondliggende beginsels van sofa fide en sola 
gratia tot uitdrukking te bring. Ook Luther en Calvyn het die begrip gebruik, maar dan in die sin van 'n eensydige testamentverhouding. Baker wys daarop dat baie wat in die sestiende eeu as verbondsteologie bestempel is, eerder testamentsteologie genoem behoort te word (Baker 1980: xxii). Met die begrip testamentum kan na twee sake verwys word: na die Ou en die Nuwe Testament (dus met ' $n$ hermeneutiese konnotasie) of na die testament van God in die sin van ' $n$ belofte (dus met ' $n$ soteriologiese konnotasie). In die meeste gevalle het die sestiendeeeuse teoloë die begrip foedus of verbond gebruik met die bedoeling van testament in die soteriologiese betekenis. Christus was dan die testamentmaker sowel as die beloofde erfdeel of erfporsie en die uitverkorenes die erfgename.

Hierteenoor het Bullinger beide begrippe foedus en testamentum gebruik om na' $n$ wederkerige verdrag of verbond te verwys. Testamentum het weliswaar ook vir hom die betekenis van 'n laaste testament of belofte gehad, maar by ' $n$ ooreenkoms met die mens deur God, het dit nie net om God se beloftes gegaan nie, maar ook die mens se bepaalde voorwaardes waartoe hy verplig was teenoor God. Vir Bullinger was die begrip testamentum dus breër as foedus en dit het sowel 'n belofte as ' $n$ wederkerige ooreenkoms of verdrag ingesluit. Bullinger het dus ' $n$ wederkerige verbond geleer wat ook die gedagte van testament ingesluit het. Vir ander Reformatore, onder andere Calvyn, het beide testamentum en foedus, in werklikheid net eensydig testament of belofte beteken.

In sy geskrif De Testamento van 1534 het Bullinger die voorwaardelike aard van die verbond nog skerper beklemtoon en ook ' $n$ duidelike onderskeid gemaak tussen foedus en testamentum. Hy het gestel dat testamentum drie betekenisse het:

- die laaste wens van ' $n$ testateur

- ' $n$ belofte wat met ' $n$ eed beloof is, dit wil sê 'n promissio en

- derdens ' $n$ verdrag (pactum) of ' $n$ verbond (foedus).

Primêr het hy testamentum as foedus verstaan, sonder egter om die ander twee betekenisse uit te sluit. Foedus daarteenoor het vir hom slegs die een betekenis van ' $n$ verdrag of verbond tussen twee partye gehad (Baker 1980: xxii). Hy het dit so gestel:

'Ein Bund (foedus) wird eingegangen oder abgeschlossen zwischen zweien oder mehreren. Diese kommen unter sich überein über die notwendigen Bedingungen und versprechen es sich und geloben gegenseitige Treue und setzen zu diesem Zweck Hauptstücke oder Underabschntte auf, die sie auf ein Blatt 
schreiben, worauf sie sie mit einen Eid oder anderen Zeremonien bekräftigen oder bestärken' (Kock 1968: 389).

Bullinger stel dat God die menslike gebruike noukeurig nagevolg het om sy verbond met die mens op te rig. In werklikheid is die Heilige Skrif die relaas van hierdie verbondsluiting wat ook die wedersydse verbondsverpligtinge van die bondgenote, naamlik God en mens, weergee (Baker 1980: 21). Die voorwaardes of verpligtinge van God se kant as die verbondstigter word gewaarborg deur die wese van God, terwyl die mens verplig word om al sy gedagtes, woorde en werke na die wil van God te skik en voor God te lewe (Koch 1968: 391).

Dit is die mens se verbondsverpligting om God te loof, te vertrou, te vereer en lief te hê as Vader, Heer en enigste Redder. Of ook anders gestel: 'Die menschliche Vertragsverplichtung im Bundesverhältnis ist der cultus Dei' (Koch 1968: 392).

As Bullinger oor die wese van die verbond skryf, dan neem hy Genesis 17:1 en volgende verse as uitgangspunt (Koch 1968: 391). Vir hom het geen twyfel bestaan dat die wedersydse verbondsverpligting reeds by die verbond met Adam gegee was nie (Baker 1980: 57), maar by Abraham het dit die duidelikste geblyk. Veral in Genesis 17:1 word die menslike verpligtinge baie duidelik gestel met die oproep om naby God te lewe en opreg te wees. Hierin was Jesus Christus ook vir die mens tot ' $n$ lewende voorbeeld wat nagevolg behoort te word. Die lewe van Christus, soos in die evangelies beskrywe, dien as 'n spieël waarin die mens kan sien wat hy behoort te doen en behoort te laat, wat God behaag en wat God mishaag (Koch 1968: 391).

\section{BULLINGER EN ZWINGLI}

Bullinger het met sy verbondsopvatting nie net met Luther en Calvyn verskil nie, maar ook met $Z$ wingli ten spyte van die feit dat hulle ten nouste met mekaar saamgewerk het. Ooreenstemming tussen hulle het daarin bestaan dat beide die eeheid van die verbond en die soteriologiese eenheid van die testamente beklemtoon het, asook dat beide oor die korporatiewe aspek van die verbond saamgestem het, naamlik dat God deur middel van die verbond vir Hom 'n volk, die kerk, gevorm het. Ook hulle sakramentsbeskouinge het ooreengekom (Baker 1980: $18)$.

Bullinger gaan egter met sy beskouing oor die wese en karakter van die verbond as ' $n$ bilaterale verdragsverhouding en met sy opvatting van die hermeneutiese eenheid tussen die testamente op 'n eie weg. Zwingli het soms wel baie naby aan 'n bilaterale verbondsleer gekom, 
maar die feit is dat sy uitverkiesingsleer so 'n verbondsopvatting uitgesluit het (Baker 1980: 16).

Tog het Zwingli waarskynlik nooit sy verbondsleer ver genoeg ontwikkel om al die konsekwensies van 'n bilaterale verbondsopvatting te deurdink nie.

\section{VERBOND EN PREDESTINASIE}

Die vraag moet nou oorweeg word of Bullinger met sy voorwaardelike verbondsopvatting nie die bekende sola fide en sola gratia in gevaar gestel het nie.

Die vraag kan ook anders gestel word: Het hierdie opvatting hom nie in 'n semi-Pelagiaanse of proto-Arminiaanse posisie geplaas nie? Die antwoord hierop is nie so eenvoudig nie, omdat Bullinger nie maklik kategoriseerbaar is nie.

Die probleem is dat hy aan die een kant uitsprake gemaak het wat sterk predestinasie-gerig was, maar aan die ander kant tog ook uitsprake gemaak het wat op 'n universalisme dui. So het hy byvoorbeeld in die Decades van 1550 predestinasie soos volg gedefinieer:

'Predestinasie is die ewige dekreet van God waardeur Hy bepaal het om mense te verlos of te vernietig, so is ' $n$ beslište eindpunt van lewe en dood voorsien' (kyk Baker 1980: 28).

Aan die ander kant het hy egter weer net so stellig verklaar dat die offer van Christus die hele wêreld van sonde reinig en aan die hele wêreld geregtigheid skenk (Baker 1980: 28). Die gevolg was dat byvoorbeeld in Nederland beide Remonstrante en Contra-Remonstrante oortuig was dat hulle hulle op Bullinger kon beroep. Tot vandag is steeds onder navorsers nie eenstemmigheid oor presies waar Bullinger tuishoort nie (Koch 1968: 94-95).

Om aan Bullinger reg te laat geskied moet sy opvattings oor predestinasie en uitverkiesing geplaas en verstaan word binne die konteks van sy bepaalde verbondsopvatting wat bilateraal of voorwaardelik van aard was. Binne die omvattende struktuur van die voorwaardelike verbond interpreteer by die sola fide en die sola gratia sonder om egter semi-Pelagiaans te wees (Pont 1984: 75).

Net soos sy verbondsopvatting het Bullinger ook sy predestinasieleer reeds baie vroeg al ontwikkel en lewenslank daarby gebly. Sy siening word deur Baker soos volg opgesom:

'His was ' $n$ moderate single predestination, with a twofold emphasis. God's election of those who believe was in, through and for Christ; therefore salvation was totally of God's free grace' (Baker 1980: 29). 
By nadere ondersoek blyk in Bullinger se verdere uitwerking van sy beskouing 'n spanning te bestaan tussen God se universele roeping en God se uitverkiesing. Die uitverkiesing het vir hom vasgestaan en die vrye wil het hy verwerp. Tog het hy terselfdertyd van ' $n$ universele roeping gepraat waarbinne die uitverkiesing in die geskiedenis gesien moet word. Dit het vir Bullinger gegaan om tegelyk God se integriteit èn die menslike verantwoordelikheid te beklemtoon, sonder om God se soewereiniteit te ontken (Baker 1980: 30). Bullinger wou van 'n dubbele predestinasie, waardeur God moontlik die outeur van die kwaad gemaak kan word, niks weet nie. God se goedheid en almag moes beklemtoon word, maar tegelyk ook die mens se verantwoordelikheid.

Baker stel dit as sy oortuiging dat hoewel Bullinger soms baie naby daaraan gekom het om sonder meer ' $n$ dubbele predestinasie te aanvaar, hy tog nooit sover gegaan het nie. Hy het telkens sy standpunt gekwalifiseer. Juis hier het Bullinger en Calvyn ook van mekaar verskil (Baker 1980: 32). Vir Calvyn het predestinasie die sola fide geimplementeer en die sola gratia beskerm (Baker 1980: xxii). Bullinger, weer, het nie die spanning wat hy gemeen het wel in die Skrifte gevind kan word, tussen die voorwaardelike verbond en sola gratia, probeer oplos nie. Calvyn se praedestinatio gemina het vir Bullinger te veel daarna geneig om God die outeur van die sonde te maak (Baker 1980: 35).

Bullinger se predestinasieleer, geplaas binne die konteks van sy bepaalde verbondsleer, kom ook in die Tweede Switserse Geloofsbelydenis na vore. In Caput VIII, wat handel oor die sondeval, is hy baie versigtig om nie op enige wyse God die outeur of oorsaak van die sonde te laat wees nie, hoewel God die mens toegelaat het om te sondig. Dit was nie 'n dekreet van God dat die sondeval moes plaasvind nie (Baker 1982: 45). Die verwerping was daarom nie die oorsaak nie, maar wel die gevolg van die sonde. Ook in Caput $x$, oor predistinasie en uitverkiesing, word slegs 'n enkele predestinasie gestel en word daar nie oor ' $n$ moontlike dubbele predestinasie gespekuleer nie. Die uitverkiesing vind egter nie plaas op grond van enige verdienste nie, maar wel in Christus en ter wille van Christus. Geloof was die teken van die uitverkiesing. Daar is egter nagevors wat meen dat die Konfessie wel deeglik 'n dubbele predistinasie leer, maar tog met sekere voorbehoude. Koch verwys met instemming na Walser 'das auch die Confessio die doppelte Prädestination vorausgesetzt, aber bewust nicht ausführt' (Koch 1968: 94). Pfister oordeel weer:

'Wohl finden sich bei ihm ebenfalls die formulierungen der doppelten Prädestination, sie sind aber nicht deterministisch ausgewertet, sondern streng christologisch verstanden' (Koch 1968: 94). 
As Koch ingaan op die vraag na 'n universalisme of partikularisme as agtergrond van die predestinasieleer van die Konfessie, besluit hy dat so ' $n$ vraag in der waarheid onvanpas ten opsigte van die Konfessie was. Hy stel:

'Die Haltung der Confessio ist terminologisch wie sachlich und besten ausgesprachen in dem Satz: promissiones Dei sunt universales fidelibus' (Koch 1968: 95).

Bullinger het enige spekulasie oor die gronde van uitverkiesing en verwerping ten ene male afgewys. So 'n spekulasie sou volgens hom net daarop uitloop 'Gottes Geheimnis zu erfüntelen' (Koch 1968: 94).

Baie belangrik is ook Bullinger se noue verbintenis tussen die verbond, predestinasie en die sakramente (Confessio Helvetica Posterior, Caput XIX). Hy het die sakramente beskryf as uiterlike heilige aksies, tekens en seëls van God se verbond (Baker 1980: 52). Deur die sakramente word die Christen herinner aan sy verlossing deur God, maar ook aan sy verbondsverpligtinge teenoor God en mens. Meer in besonder is die doop (Caput XX) ' $n$ inlywing in die verbondsgemeenskap, die kerk, die volk en die familie van erfgename van God. Elkeen wat in die verbond opgeneem is, gedoop is, is dan uitverkore en moet as sodanig beskou word. Alleen as 'n gedoopte later die verbond eksplisiet sou verwerp, sou moontlik geoordeel kan word dat so 'n persoon nie uitverkies was nie, maar wel verwerp.

Opsommend kan gestel word dat Bullinger die verbond en predestinasie ten nouste verbind het. Die verbond was die historiese konteks waarbinne God met sy volk gehandel het. Bullinger het geen teoretiese, abstrakte of spekulatiewe dogma ontwikkel nie (Baker 1980: 53). Hy wou op die prakties-historiese vlak Bybelgetrou bly. Baker formuleer dit soos volg:

'Bullinger was content to present his understanding of the biblical teaching of single predestination within the context of a universal atonement. When pressed he always cited the universalist passages of the Bible. He never attempted to reconcile everything in a closely reasoned and logical theory of double predestination. Instead he cast his doctrine of salvation within the framework of the covenant, which meant that predestination only made sense within the historical calling of man by God' (Baker 1980: 53).

\section{BULLINGER EN DIE CHRISTELIKE GEMEENSKAP}

Bullinger se verbondsleer het ook die grondslag van sy unieke opvat- 
ting ten opsigte van die Christelike gemeenskap en die dissipline gelê (Baker 1980: xxiii en 107). Sy ideaal was 'n Christelike gemeenskap binne die verbond waaroor die Christelike magistraat soewereine outoriteit gehad het. Die Christelike magistraat was verantwoordelik vir die handhawing van die verbondsvoorwaardes binne die gemeenskap. Dit het ingehou dat die burgerlike owerheid in absolute beheer van die dissipline was en dit het ook vir die kerk gegeld. Hierin het Bullinger totaal van veral Calvyn wat die ekskommunikasie en kerklike dissipline in die hande van die kerkraad geplaas het, verskil.

Uitgaande van die feit dat daar vanaf Adam tot op hede net een verbond, een geloof en een kerk was, stel Bullinger dat die norme vir die Christelike gemeenskap reeds ten volle in die Ou Testament gevind word en slegs in die Nuwe Testament verder belig word. In Israel het elkeen wat in die verbond ingelyf is, deur die sakrament van die besnydenis gedeel in die verbondsbeloftes en verbondsverpligtinge. Net so, na Christus, het die doop as inlywingsrite die individu in die Godsvolk opgeneem, hom onder die verbondsbeloftes geplaas en daarmee saam onder die verbondsverpligtinge (Baker 1980: 107). Net soos in Israel, was die verbondsvoorwaardes in die Christelike gemeenskap op die hele gemeenskap van toepassing, omdat die sigbare kerk en die gemeenskap in wese saamgeval het. Dit was dieselfde volk van God wat kerk en gemeenskap gevorm het.

Bullinger het nie in terme van kerk en staat gedink nie, maar eerder aan die volk van God wat vergader is in 'n Christelike gemeenskap wat op die verbond gebaseer is. Die kerk het nie in die gemeenskap bestaan nie, maar was die gemeenskap. In hierdie Christelike gemeenskap het die pastor sy funksies gehad en die burgerlike regeerder syne. Die regeerder het nie gepreek en sakramente bedien nie en die pastor het weer nie regeer en regspraak uitgeoefen nie. Dan gaan Bullinger verder en ken aan die burgerlike regeerder ook seggenskap oor die kerkregering toe. Hier het Bullinger baie sterk teruggegryp op Israel waar die rigters en konings oor die hele lewe van die Godsvolk moes regeer; ook oor die kerk en sy godsdienstige lewe. Sowel in $\mathrm{Ou}$ en Nuwe Testament moes die kerklike ampsdraers die verbondsbeloftes en -voorwaardes aan volk en regeerders uitspel en hulle tot onderhouding oproep. Hulle het egter geen tugreg gehad nie.

Die burgerlike regeerder het weer die groot verantwoordelikheid gehad om toe te sien dat elke lid van die gemeenskap die verbondsverpligtinge gehoorsaam, selfs al moes hy dwang gebruik. Bullinger se redenasie was dat in die Ou Testament onderskei kan word in 'n 
seremoniële en morele wet. Die morele wet is niks anders as die verbondsverpligtinge van die mens nie. Na Christus se koms het die seremoniële verdwyn, maar die morele het gebly. Op die blywende morele wet of verbondsverpligtinge, moet die regeerder nou sy wette baseer as verdere verduidelikings van die verbondsverpligtinge. Die regeerder moet dan toesien dat hierdie wette, wat ' $n$ nadere omskrywing van die verbondsnorme was, gehoorsaam word deur elke lid van die gemeenskap, hetsy vrywillig of deur dwang (Baker 1980: 65-68).

In Caput XXX van die Tweede Switserse Geloofsbelydenis oor die owerheid, het Bullinger se gedagtes neerslag gevind. Eerstens word gestel dat die owerheid 'n instelling van God was. Die regeerder moes godvresend en godsdienstig wees en die voorbeeld van die konings en prinse van die volk van God navolg deur die prediking van die waarheid en die opregte geloof te bevorder, die bygeloof, leuens, goddeloosheid en afgodery uit te roei en die kerk te verdedig. Die bewaring en beskerming van die godsdiens is veral aan die regeerder opgedra. Daarom moes die regeerder die Woord van God gehoorsaam en daarteen waak dat niks in stryd met die Woord geleer sou word nie. Hy moes met goeie wette, wat op God se Woord berus het, die volk dissiplineer en tot plig en gehoorsaamheid aanspoor.

Dit is uit die voorgaande te verstane dat dit Bullinger se eis was dat die regeerder 'n vroom, godvresende, gehoorsame Christen moes wees. Die lot van die gemeenskap het net soos dié van die kerk byna geheel en al gerus op die geloof, godsdienstigheid en karakter van die regeerder (Baker 1980: 71 en 114). Juis hier lê waarskynlik die swakheid in Bullinger se hele teorie, naamlik sy geweldige vertroue in die Christelike regeerder en die beklemtoning van die soewereiniteit van die regeerder (Baker 1980: 140). Hierdie vertroue op die Christelike regeerder spruit weer uit Bullinger se baie sterk vertroue in die krag van die Woord van God. Hy stel dat daar niks te vrees was solank die pastors vry en sonder belemmering die Woord kan bly preek nie. As dit maar gebeur sal God self onder sy volk werk.

Afsluitend kan gestel word dat Bullinger se verbondsmatige gedagtes rondom die Christelike gemeenskap en die soewereiniteit van die burgerlike regering baie naby gekom het aan die gedagtes van ondeelbare soewereiniteit ('indivisible sovereignty') wat in die denke van byvoorbeeld Erastus en Bodin voorgekom het (Baker 1980: 171-173). Bullinger het egter nooit 'n teorie van staatsabsolutisme ontwerp of voorgestaan nie. 


\section{BULLINGER SE INVLOED}

Bullinger het met sy verbondsdenke groot invloed in die vroeë gereformeerde Protestantisme gehad. Die wye aanvaarding van die Tweede Switserse Konfessie het hierin 'n belangrike bydrae gelewer. Ook buite die Switserse kerk het Bullinger se verbondsteologie weerklank gevind. Soms weer het sy verbondsteologie, waarin daar in sekere opsigte ' $n$ ambivalensie aan te toon is, as outoritêre grond gedien vir teenstrydige gedagtes en opvattinge.

In Skotland het John Knox die basis gelê waarop die kenmerkende Skotse 'national covenants' gebou is. Vir sy gedagtes het Knox baie sterk gesteun op advies van Bullinger veral ten opsigte van gewapende opstand teen die owerheid. Iets wat nie sonder meer deur Bullinger afgewys is nie, juis as gevolg van sy bepaalde verbondsbeskouing en die verantwoordelikheid van die regeerder om toe te sien dat die verbondsverpligtinge nagekom moes word (Pont [1973]: 54).

In Frankryk het die skrywer van die Vindiciae contra tyrannos (1579), wat waarskynlik Philippe Duplessis-Mornay was, se verbondsgedagtes byna met dié van Bullinger ooreengekom. Hy het egter ander meer radikale implikasies uit die verbondsverhouding as Bullinger afgelei (Baker 1980: 174).

In Nederland het Bullinger se verbondsteologie ook groot invloed gehad. 'n Tweërlei lyn in die ontwikkeling van die verbondsteologie het veral daar na vore gekom wat beide op die outoriteit van Bullinger teruggegryp het, maar tog in ernstige botsing met mekaar gestaan het. Die eerste was die lyn wat oor Anastasius Veluanus na die Remonstrante geloop het en waar 'n sterk afkeer van die leer van die predestinasie bestaan het. In hierdie kringe het die verbondsteologie egter nie werklik verder ontwikkel nie.

Die tweede lyn het weer oor Gellius Snecanus, Ursinus en Olevianus, die Heidelbergse Kategismus, Gomarus, Amesius en Cloppenburg tot by Coccejus geloop (Oorthuys en Kromsigt 1933: 21). By Coccejus het die saak so tot ontwikkeling gekom dat van ' $n$ 'foederaal'-teologie in die volle sin van die woord gepraat kan word. Coccejus het die totale openbaring van God aan en die totale handeling van God met die mens, as verbond gesien. Die verbondsleer was by hom nie maar net meer ' $n$ locus in die dogmatiek nie, maar dit was die teologie self (Oorthuys en Kromsigt 1933: 24). Coccejus word dan ook deur baie beskou as die vader van die 'foederaal'-teologie.

Ten slotte kan net nog vir 'n oomblik na die gebeure by Dordt 1618-1619 verwys word waar beide die Remonstrante en Contra-Re- 
monstrante hulle op Bullinger as outoriteit beroep het. Vir Johann Jacob Breitinger, die leier van die afvaardiging van die Switserse kerke was dit veral 'n verleentheid omdat die Remonstrante so op Bullinger aanspraak gemaak het. Breitinger het daarom met groot stelligheid verklaar dat Bullinger inderdaad Calvyn se leer van die praedistinatio gemina gedeel het en dat die Remonstrante hulle dus nie op Bullinger kon beroep nie.

Baker toon egter aan dat Breitinger daarmee nie aan Bullinger se standpunt reg laat geskied het nie. Waarskynlik sou Bullinger eerder van beide groepe verskil het. Bullinger was nie, soos sommige dink, 'n universalis nie en hy het nooit verkondig dat enige mens op grond van 'n vrye, eie wil kan glo nie. Geloof was God se gawe aan sy uitverkorenes. Aan die ander kant het hy tog nie Calvyn se praedestinatio gemina gedeel nie. Hierdie dubbelslagtigheid kan aan Bullinger se bepaalde verbondsteologie toegeskryf word (Baker 1980: 47).

\section{Literatuurverwysings}

BAKER, JW 1980. Heinrich Bullinger and the covenant: The other Reformed Tradition. Chico: Ohio University Press.

DE KLERK, PJS 1954. Gereformeerde simboliek. Pretoria: Van Schaik.

KOCH, E 1968. Die Theologie der Confessio Helvetica Posterior: Beiträge zur Geschichte und Lehre der reformierten Kirche, Band XXVII. Neukirchener: Verlag.

LEITH, JH 1973. Creeds of the churches. Revised Edition. Oxford.

OORTHUYS, G \& KROMSIGHT, P 1933. Grondslag en wezen der Kerk. Wageningen: Veenman en Zonen.

PONT, AD [1973]. Opmerkings oor die covenantgedagte by John Knox en Skotse Reformasie, HTS 29, 48-60.

PONT, AD 1984. Die kinderdoop en die verbond by die Reformatore Zwingli en Byllinger: 'n Kort oorsig. HTS 40/3, 68-78. 